\title{
Pengaruh Kemasan Plastik Polietilen dan Polipropilen terhadap Umur Simpan Abon Ikan Tongkol (Katsuwonus pelamis) dengan Menggunakan Model Arrhenius

\author{
(Effect of Polyethylene and Polypropylene Plastics Packaging on The Shelf Life of Tuna Fish \\ (Katsuwonus pelamis) Using Arrhenius Model)
}

\author{
M. Rizki Arifandy Saragih ${ }^{1}$, Martunis ${ }^{1}$, Ismail Sulaiman ${ }^{1 *}$ \\ ${ }^{1}$ Program Studi Teknologi Hasil Pertanian, Fakultas pertanian, Universitas Syiah Kuala
}

\begin{abstract}
Abstrak: Tujuan penelitian ini yaitu untuk mengetahui umur simpan pada abon ikan dengan metode Arrhenius berdasarkan jenis kemasan dan suhu penyimpanan. Penelitian ini dilakukan dengan menggunakan metode akselerasi pendugaan umur simpan abon ikan. Pendugaan umur simpan ini ditentukan melalui perubahan mutu abon ikan berdasarkan dua faktor. Faktor I adalah jenis kemasan yang terdiri dari 2 taraf yaitu : K1= PE, K2= PP. Faktor II adalah suhu penyimpanan terdiri atas 3 taraf yaitu : $\mathrm{S} 1=30^{\circ} \mathrm{C}, \mathrm{S} 2=40^{\circ} \mathrm{C}$ dan $\mathrm{S} 3=50^{\circ} \mathrm{C}$. Penyimpanan abon (hari) terdiri atas 5 taraf yaitu : $\mathrm{P} 0=0$ hari, $\mathrm{P} 1=7$ hari, $\mathrm{P} 2=14$ hari, $\mathrm{P} 3=21$ hari dan $\mathrm{P} 4=28$ hari. Dengan demikian diperoleh 60 satuan percobaan. Dari hasil penelitian ini diperoleh umur simpan abon ikan yang dikemas dengan kemasan PE dengan suhu $30^{\circ} \mathrm{C}=113$ hari. Pada suhu $40^{\circ} \mathrm{C}=108$ hari. Pada suhu $50^{\circ} \mathrm{C}=104$ hari. Sedangkan umur simpan abon ikan dengan kemasan PP pada suhu $30^{\circ} \mathrm{C}=63$ hari. Pada $40^{\circ} \mathrm{C}=62$ hari. Pada suhu $50^{\circ} \mathrm{C}=61$ hari.
\end{abstract}

Kata kunci : abon, Arrhenius, suhu, polietilen, polipropilen.

\begin{abstract}
The purpose of this study is to find out the shelf life of abon fish by Arrhenius method based on the type of packaging and storage temperature. This research was done by using acceleration method of shelf life estimation of abon fish. The estimation of shelf life is determined by changes in the quality of fish abon based on two factors. The first factor is the type of packaging consist of 2 levels, namely: K1 = PE, K2 = PP. Second factor is the storage temperature consists of 3 levels, namely: $\mathrm{S} 1=30^{\circ} \mathrm{C}, \mathrm{S} 2=40^{\circ} \mathrm{C}$ and $\mathrm{S} 3=50^{\circ} \mathrm{C}$. Analysis performed during storage (day) consists of 5 levels ie: $\mathrm{P} 0=0$ days, $\mathrm{P} 1=7$ days, $\mathrm{P} 2=14$ days, $\mathrm{P} 3=21$ days and $\mathrm{P} 4=28$ days. Thus there were 30 treatment combinations with 2 replications so obtained 60 units of treatment. Result of the study showed that the shelf life of abon fish packed with PE packaging with a temperature of $30^{\circ} \mathrm{C}=113$ days. At $40^{\circ} \mathrm{C}=108$ days. At $50^{\circ} \mathrm{C}=104$ days. While the shelf life of abon fish with PP packaging at $30^{\circ} \mathrm{C}=63$ days. At $40^{\circ} \mathrm{C}=62$ days. At $50^{\circ} \mathrm{C}$ $=61$ days.
\end{abstract}

Keywords: abon, Arrhenius, temperature, polyethylene, polyprophylene.

\section{PENDAHULUAN}

Ikan merupakan bahan pangan hewani yang banyak dikonsumsi oleh masyarakat Indonesia, karena memiliki kandungan gizi yang lengkap seperti protein, lemak, mineral dan vitamin yang sangat dibutuhkan oleh manusia. Namun demikian, ikan juga tergolong jenis bahan pangan hewani yang mudah mengalami proses pembusukan, salah satunya yakni jenis ikan tongkol (Euthynnus affinis). Upaya yang perlu dilakukan untuk menghambat proses pembusukan tersebut yaitu dengan cara pengawetan dan pengolahan (Sugiarto dkk., 2015).

Corresponding author: ismail.sulaiman@unsyiah.ac.id

JIM Pertanian - THP, Vol. 4, No. 2, 2019: 317-328 
Abon adalah salah satu olahan makanan kering yang dibuat dari daging dengan cara direbus, disayat, digoreng dan dipres lalu ditambahkan bumbu sehingga memiliki cita rasa yang khas. Abon ikan merupakan jenis makanan yang terbuat dari ikan dan diolah dengan cara direbus kemudian digoreng lalu diberi bumbu (Suryani dkk, 2007). Ada dua hal penyebab kerusakan bahan pangan yaitu kerusakan yang disebabkan oleh sifat alamiah dari produk yang berlangsung secara spontan dan yang kedua disebabkan karena pengaruh lingkungan. Oleh karena itu untuk mencegah atau menunda proses kerusakan perlu dilakukan pengemasan sehingga bahan pangan mempunyai daya simpan yang lebih lama (Nur, 2009).

Pengemasan sangat berpengaruh terhadap masa simpan dan mutu abon sehingga harus dilakukan pengemasan dan penyimpanan yang baik. Menurut Syarief dkk., (1989 dalam Azriani, 2006), hal ini dimaksudkan untuk mempertahankan produk agar tetap baik dan memberikan perlindungan pada produk dari kerusakan fisik seperti air, oksigen, sinar, dan pencemaran lain seperti kotoran. Pengemasan abon umumnya menggunakan kemasan plastik yaitu plastik jenis polietilen (PE) dan plastik polipropilen (PP).

Pada penelitian ini dilakukan penyimpanan terhadap abon ikan dengan perlakuan terbaik untuk menduga umur simpan abon ikan. Metode yang digunakan yaitu metode Accelerated Storage Studies (ASS) atau disebut juga dengan Accelerated Shelf-Life Testing (ASLT) dengan menggunakan pendekatan semi empiris dengan persamaan Arrhenius. Metode ini dilakukan dengan menggunakan suatu kondisi yang dapat mempercepat proses penurunan mutu produk pangan. Penentuan umur simpan berdasarkan peningkatan suhu dilakukan untuk mengetahui perubahan mutu selama penyimpanan yang dipengaruhi oleh kondisi suhu penyimpanan.

\section{METODE PENELITIAN}

Penelitian dilakukan di Laboratorium Mikrobiologi Pangan dan Industri, Laboratorium Analisis Hasil Pangan dan Hasil Pertanian, Laboratorium Rekayasa Proses Pangan dan Industri dan Laboratorium Uji Sensori Jurusan Teknologi Hasil Pertanian, dan Laboratorium Benih Jurusan Agroteknologi Fakultas Pertanian Universitas Syiah Kuala Banda Aceh. Pada bulan Agustus-September 2017

\section{MATERI DAN METODE}

\section{Bahan dan Alat}

Bahan yang digunakan dalam pembuatan abon ikan adalah Ikan Tongkol dan beberapa bahan tambahan yaitu serai, daun salam, bawang merah, bawang putih, garam, ketumbar dan santan. Sedangkan bahan kimia yang di gunakan untuk analisis yaitu Aquades, asam klorida (HCL) 4 N, larutan 0,02 M asam thiobarbiturat, alkohol, pepton, media PCA (Plate Count Agar) serta bahan pengemas plastik polietilen $(0,1 \mathrm{~mm})$ dan polipropilen $(0,25 \mathrm{~mm})$.

Alat yang digunakan pada penelitian ini adalah beaker glass, labu destruksi, oven, tabung reaksi, pipet volume, pipet tetes, desikator, cawan petri, incubator, autoklaf, destilasi, spektrofotometer, timbangan analitik, batang pengaduk, gelas ukur, Erlenmeyer, pH meter dan Quebec Colony Counter.

Pengaruh Jenis Kemasan Plastik Polietilen dan Polipropilen terhadap Umur Simpan Abon Ikan Tongkol (Katsuwonus pelamis) dengan Pendekatan Metode Arrhenius (M. Rizki Arifandy Saragih, Ismail Sulaiman, Martunis) 


\section{Rancangan Penelitian}

Penelitian ini dilakukan dengan menggunakan metode akselerasi pendugaan umur simpan abon ikan. Pendugaan umur simpan ini ditentukan melalui perubahan mutu abon ikan berdasarkan dua faktor. Faktor I adalah jenis kemasan yang terdiri dari 2 taraf yaitu : K1= PE, K2= PP. Faktor II adalah suhu penyimpanan terdiri atas 3 taraf yaitu : $\mathrm{S} 1=30^{\circ} \mathrm{C}, \mathrm{S} 2=40^{\circ} \mathrm{C}$ dan $\mathrm{S} 3=50^{\circ} \mathrm{C}$. Penyimpanan abon (hari) terdiri atas 5 taraf yaitu : $\mathrm{P} 0=0$ hari, $\mathrm{P} 1=7$ hari, $\mathrm{P} 2=14$ hari, $\mathrm{P} 3=21$ hari dan P4= 28 hari. Setiap perlakuan diulang 2 kali. Dengan demikian diperoleh 60 satuan percobaan.

\section{Pembuatan Abon}

Ikan dibersihkan, dibuang isi perut, kepala dan sisik. Kemudian dicuci bersih sampai darah tidak ada. Ikan dibagi menjadi beberapa bagian. Ikan ditambahkan perasan air jeruk nipis. Selanjutnya ikan tongkol di rebus hingga lunak. Daging ikan dipisahkan dengan tulangnya (difillet) dan ditumbuk dengan pelan-pelan sehingga berupa serat - serat halus. Kemudian ditambahkan bumbu-bumbu lengkuas dan sereh dipukul - pukul sampai memar. Bawang merah, bawang putih, ketumbar digiling halus, kemudian ditumis. Setelah agak harum, ditambahkan santan kental, lengkuas, asam jawa, gula, daun salam, dan sereh. Pemanasan diteruskan sampai mendidih dan volume santan tinggal setengahnya.

Selanjutnya dimasak diatas kompor dengan menggunakan suhu dibawah $100^{\circ} \mathrm{C}$ dengan api kecil. Kemudian campuran suiran daging ikan dan bumbu dimasukkan dalam wajan dengan ditambahkan daun jeruk. Suiran daging diaduk sampai 3 jam. Abon yang telah disangrai kemudian diangin-anginkan. Kemudian ditambahkan bawang goreng. Selanjutnya dikemas dengan kemasan Polietilen dan Polipropilen. Produk abon ikan disimpan pada suhu yang berbeda yaitu suhu $30^{\circ} \mathrm{C}, 40^{\circ} \mathrm{C}$, dan $50^{\circ} \mathrm{C}$ dengan lama penyimpanan pada $0,7,14,21$ dan 28 hari.

\section{Analisis}

Analisis yang dilakukan terhadap abon ikan meliputi kadar air, uji Thiobarbituric Acid (TBA), total colony counter (TCC) dan uji organoleptik meliputi uji deskriptif (warna, aroma dan tekstur).

\section{Analisis data}

Analisis data yang dilakukan untuk mengetahui pengaruh jenis kemasan terhadap umur simpan abon ikan dilakukan analisis dengan metode Arrhenius. Hasil analisis parameter tiap perlakuan diplotkan terhadap waktu penyimpanan. ordo nol $\mathrm{y}=\mathrm{C}_{\mathrm{t}}$ dan $\mathrm{x}=\mathrm{t}$; ordo satu, $\mathrm{y}=\ln \mathrm{C}_{\mathrm{t}}$ dan $\mathrm{x}=\mathrm{t}$. Berdasarkan grafik, diperoleh persamaan linear $\mathrm{y}=\mathrm{ax}+\mathrm{b}$ dan nilai korelasinya $\left(\mathrm{R}^{2}\right)$, dimana $\mathrm{a}=\mathrm{k}=$ slope, $\mathrm{b}=\mathrm{C}_{0}=$ intersep ( untuk ordo nol), dan $\mathrm{b}=\ln \mathrm{C}_{0}=$ intersep (untuk ordo satu). Nilai k yang diproleh dari point 2 selanjutnya dimasukkan ke dalam persamaan matematis waktu masa simpan untuk masing-masing orde.

Untuk ordo nol $t=\frac{A_{0}-A_{t}}{k}$, untuk ordo satu $t=\frac{\ln \left(A_{0}\right)-\ln \left(A_{\mathrm{t}}\right)}{k}$. 


\section{HASIL DAN PEMBAHASAN}

\section{Kadar Air}

Kadar air yang dihasilkan dengan menggunakan kemasan PE berkisar antara 5,16\%-6,99\% dengan nilai rata-rata 6,43\% dan analisis kadar air dengan menggunakan kemasan PP berkisar antara 3,86\% -6,99\% dengan nilai rata-rata 6,00\%.

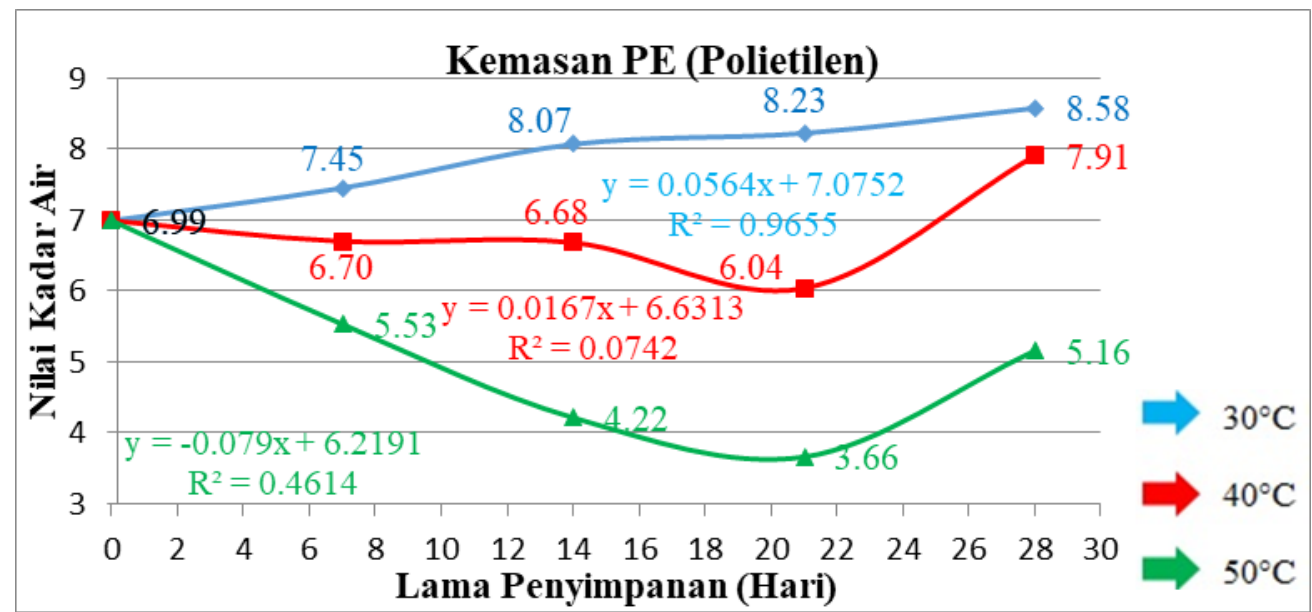

Gambar 1. Grafik perubahan nilai kadar air abon ikan dengan kemasan PE pada perbedaan suhu dan lama penyimpanan.

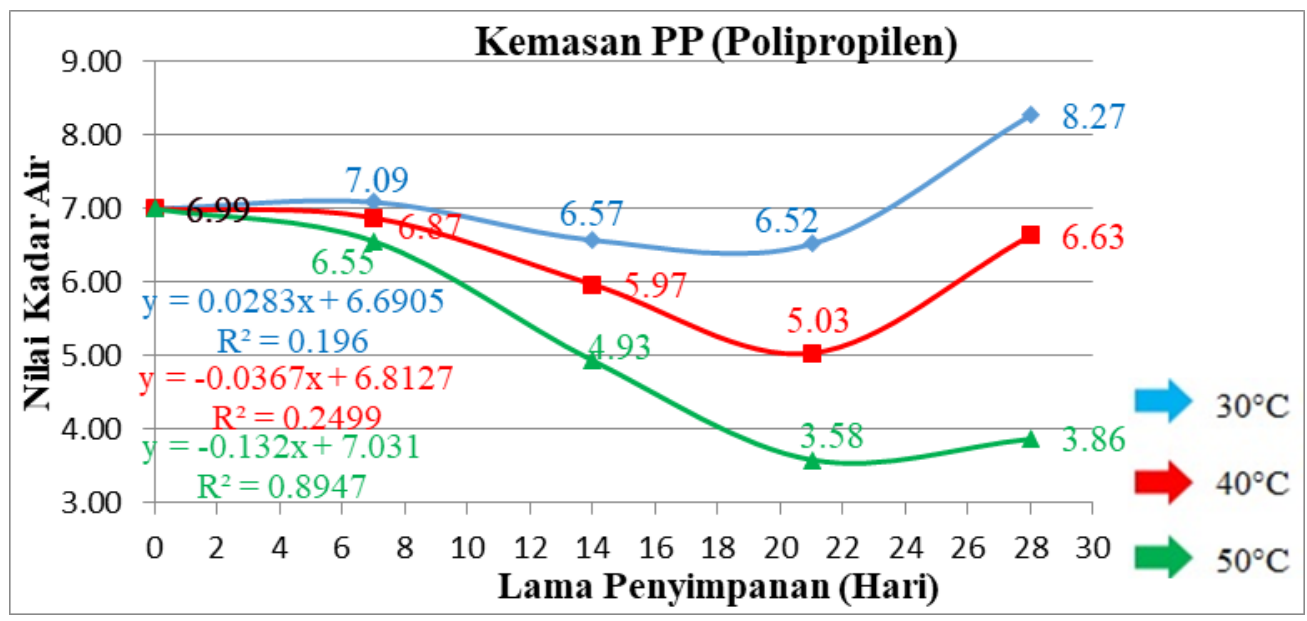

Gambar 2. Grafik perubahan nilai kadar air abon ikan dengan kemasan PP pada perbedaan suhu dan lama penyimpanan.

Pengaruh Jenis Kemasan Plastik Polietilen dan Polipropilen terhadap Umur Simpan Abon Ikan Tongkol (Katsuwonus pelamis) dengan Pendekatan Metode Arrhenius (M. Rizki Arifandy Saragih, Ismail Sulaiman, Martunis)

Jurnal Ilmiah Mahasiswa Pertanian, Vol. 4, No. 2. 2019: 317-328 
Selama penyimpanan kadar air abon ikan pada suhu $30^{\circ} \mathrm{C}, 40^{\circ} \mathrm{C}$ dan $50^{\circ} \mathrm{C}$ cenderung menurun dari hari ke-0 sampai hari ke-21 dan mengalami kenaikan sampai hari ke-28. Diduga pada hari ke-0 sampai hari ke-21 kadar air pada bahan dimanfaatkan oleh mikroba untuk berkembang biak sehingga kadar air pada bahan menurun, sedangkan pada hari ke-21 sampai hari ke-28 mikroba yang ada pada bahan sudah tidak ada lagi dan air yang dipakai akan dilepas kembali sehingga kadar air pada bahan menjadi naik. Menurut Arizka dan Daryatmo (2015), produk yang dapat menyerap air selama penyimpanan dengan nilai RH 75-80\% dapat mengalami penyerapan uap air dan perubahan sifat fisik pada bahan pangan. Penyerapan kadar air di udara dapat menyebabkan kadar air dan aktivitas (aw) pada bahan pangan meningkat. Hal ini sesuai dengan pernyataan Retnani dkk., (2008) yang menyatakan bahwa kelembaban udara pada ruang penyimpanan yang tinggi dapat menyebabkan terjadinya proses absorbsi uap air dari udara ke bahan yang mengakibatkan peningkatan kadar air.

Abon ikan yang dikemas dengan menggunakan kemasan PE menunjukkan penurunan kadar air yang lebih kecil dibandingkan dengan kemasan PP. Menurut Budiyanto (2012), hal ini disebabkan permeabilitas terhadap gas dan uap air pada plastik PE lebih rendah dibandingkan dengan kemasan PP sehingga pertukaran gas dan uap air tidak mudah terjadi.

\section{Total Colony Counter (TCC)}

Analisis total colony counter bertujuan untuk mengetahui jumlah mikroorganisme yang terkandung dalam produk yang dihasilkan. Perubahan total mikroorganisme pada abon ikan dapat dilihat pada Gambar 3 dan 4.

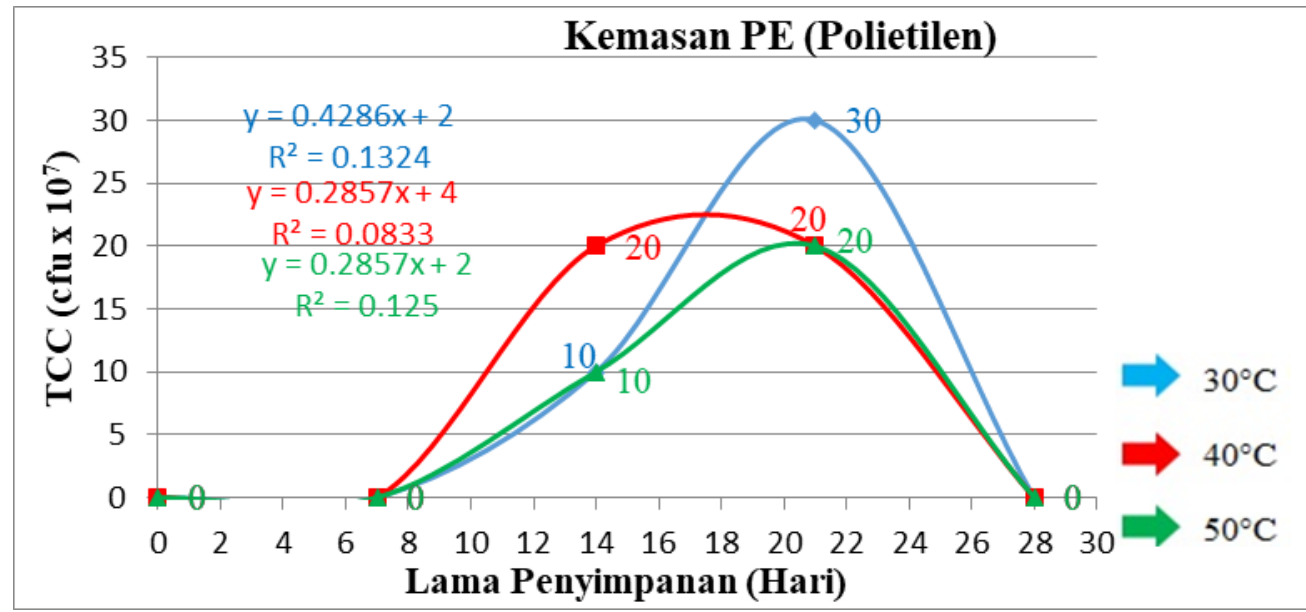

Gambar 3. Grafik perubahan total colony counter abon ikan dengan kemasan PE pada perbedaan suhu dan lama penyimpanan. 


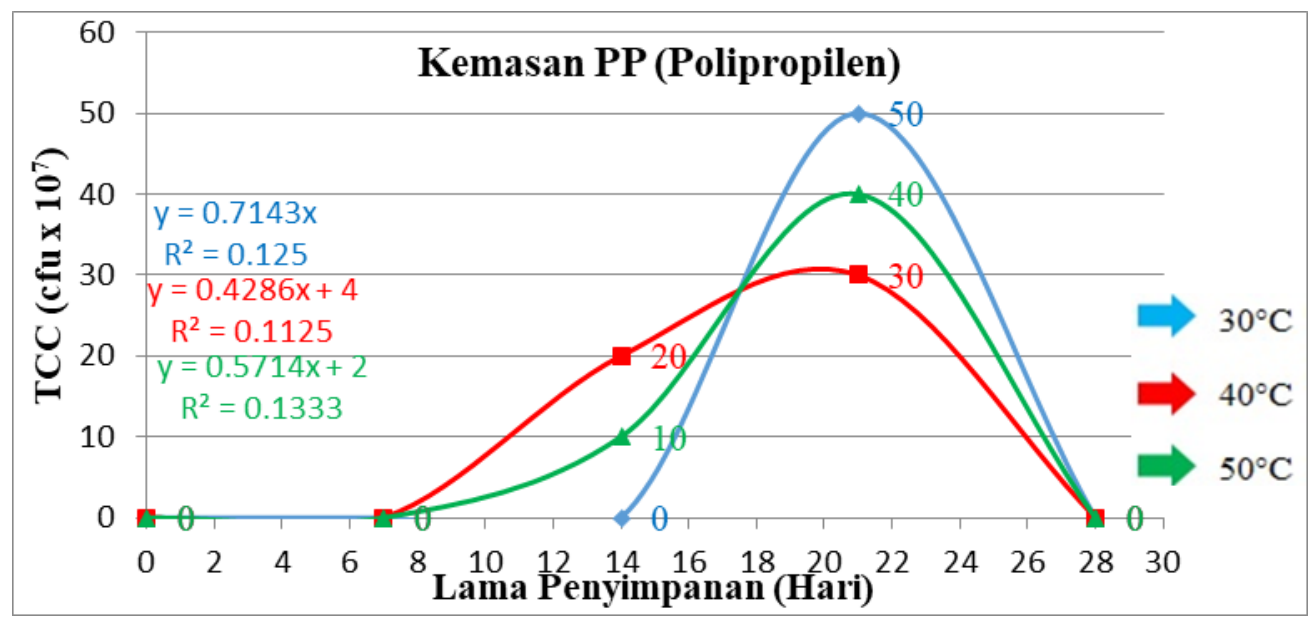

Gambar 4. Grafik perubahan total colony counter abon ikan dengan kemasan PP pada perbedaan suhu dan lama penyimpanan

\section{Uji TBA (Thiobarbituric Acid)}

Hasil analisis TBA dengan kemasan PE (Gambar 5) berkisar antara 0,3253-0,5101 mg malonaldehid/kg sedangkan dengan kemasan PP (Gambar 6) berkisar antara 0,3253-0,5769 mg malonaldehid/kg. Nilai TBA abon ikan selama penyimpanan dan setiap perlakuan cenderung mengalami peningkatan.

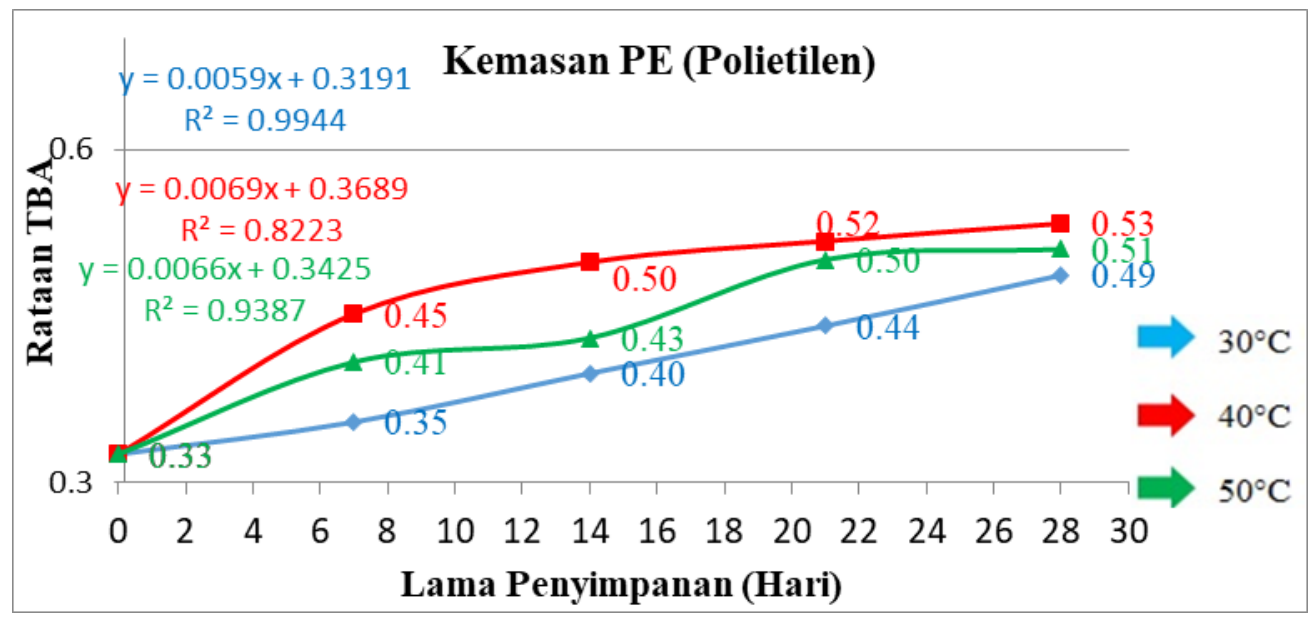

Gambar 5. Grafik perubahan nilai TBA abon ikan dengan kemasan PE pada perbedaan suhu dan lama penyimpanan.

Pengaruh Jenis Kemasan Plastik Polietilen dan Polipropilen terhadap Umur Simpan Abon Ikan Tongkol (Katsuwonus pelamis) dengan Pendekatan Metode Arrhenius (M. Rizki Arifandy Saragih, Ismail Sulaiman, Martunis)

Jurnal Ilmiah Mahasiswa Pertanian, Vol. 4, No. 2. 2019: 317-328 


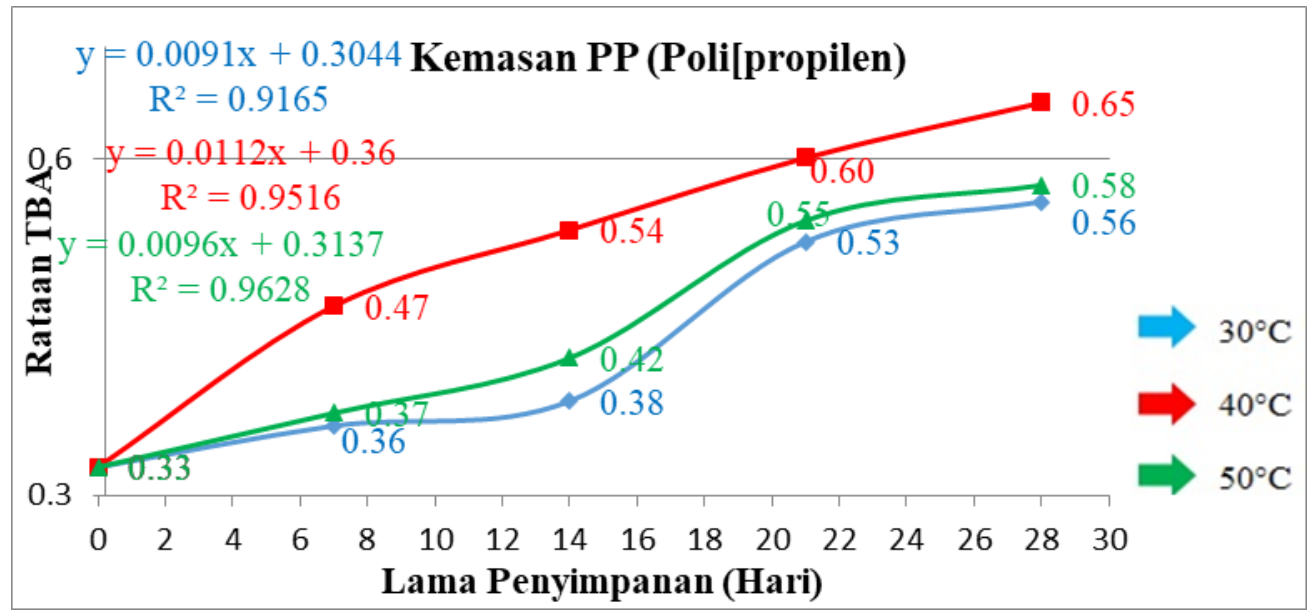

Gambar 6. Grafik perubahan nilai TBA abon ikan dengan kemasan PP pada perbedaan suhudan lama penyimpanan.

Berdasarkan bilangan TBA yang didapat, plastik PE lebih sedikit mengalami kenaikan dibandingkan dengan kemasan PP, ini disebabkan kemasan PE memiliki daya tahan terhadap oksigen yang lebih baik dibandingkan dengan kemasan PP. Menurut Budiyanto (2012), hal ini dipengaruhi oleh densitas dan permeabilitas dari masing-masing kemasan. Kemasan yang memiliki densitas yang tinggi menandakan bahwa kemasan tersebut memiliki struktur yang tertutup, artinya tidak mudah ditembusi oleh fluida dan gas (Bierley dkk., 1989) dalam Budiyanto, 2012).

\section{Uji Organoleptik (Uji Deskriptif)}

\section{Warna}

Hasil analisis organoleptik warna pada kemasan PE (Gambar 7) berkisar antara 3,27-4,37 dengan rata-rata 3,66 sedangkan pada kemasan PP (Gambar 8) berkisar antara 2,85-4,37dengan rata-rata 3,63. Dari hasil pengamatan dapat dilihat bahwa semakin tinggi suhu penyimpanan. maka semakin cepat penurunan warna pada abon ikan. Hal ini sesuai dengan pernyataan Tridiyani (2012), apabila suhu penyimpanan semakin tinggi dan semakin lama penyimpanan, warna abon ikan akan mengalami perubahan menjadi semakin coklat akibat laju oksidasi yang meningkat. Nilai warna pada abon ikan yang dikemas menggunakan kemasan PE lebih tinggi atau lebih baik dari pada abon ikan yang dikemas dengan kemasan PP. Hal ini diduga karena udara pada kemasan PE kemungkinan semua keluar, sehingga tidak terjadi interaksi oksigen yang dapat menyebabkan kerusakan warna abon ikan akibat reaksi oksidasi. 


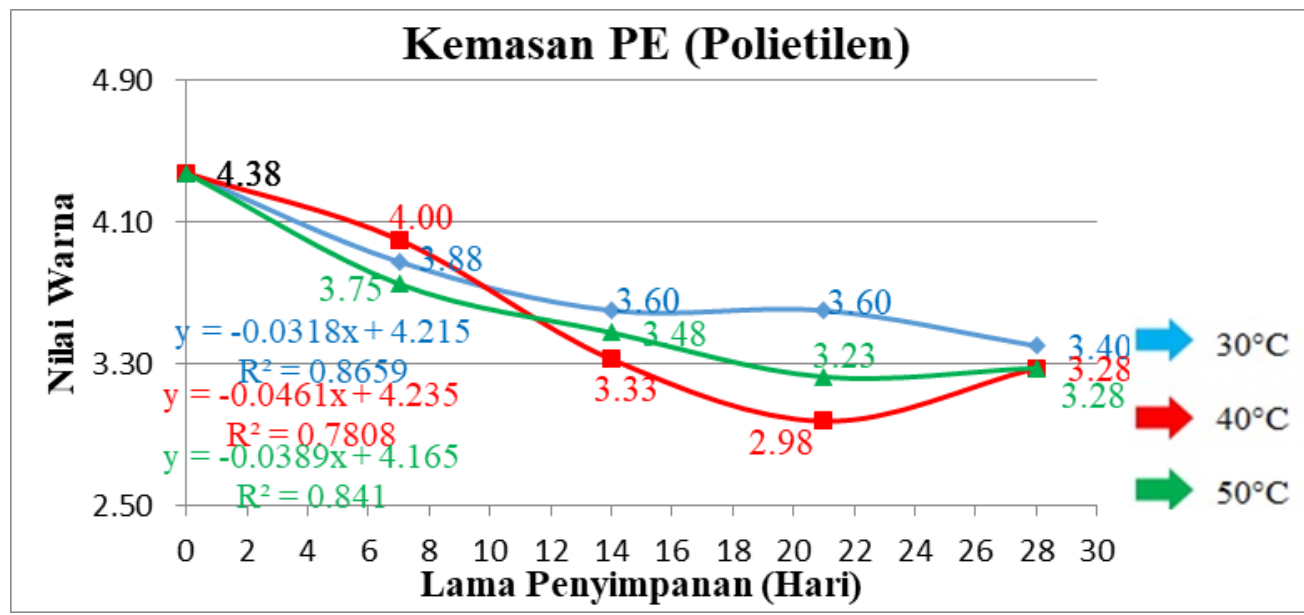

Gambar 7. Grafik perubahan nilai warna abon ikan dengan kemasan PE perbedaan suhu dan lama penyimpanan

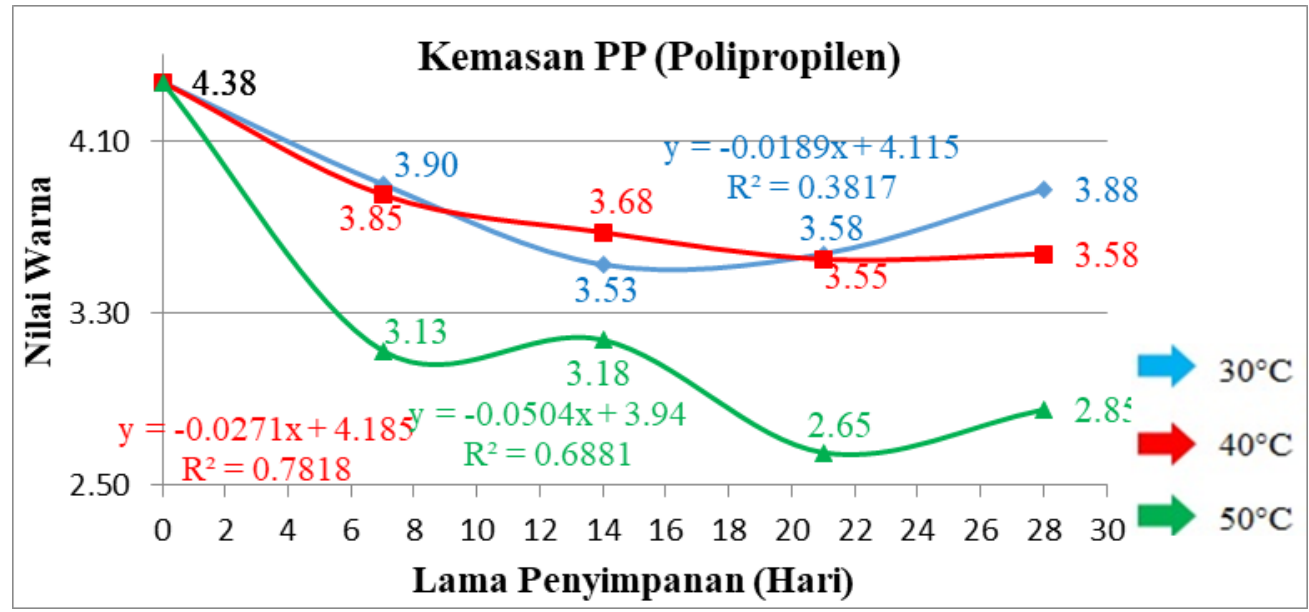

Gambar 8. Grafik perubahan nilai warna abon ikan dengan kemasan PP pada perbedaan suhu dan lama penyimpanan.

\section{Aroma}

Hasil analisis organoleptik aroma pada kemasan PE (Gambar 9) berkisar antara 2,22-3,00 dengan rata-rata 3,00 sedangkan pada kemasan PP (Gambar 10) berkisar antara 2,12-3,00 dengan rata-rata 3,025. Dari hasil pengamatan diambil dari rata-rata setiap uji dan parameter aroma dari abon ikan dan didapatkan hasil cenderung menurun yang disebabkan oleh faktor suhu dan lama penyimpanan. Menurut Tridiyani (2012), perubahan aroma abon ikan akibat meningkatnya suhu dan lama penyimpanan menyebabkan terjadinya reaksi oksidasi dalam bahan sehingga mengakibatkan bau tengik pada abon ikan.

Pengaruh Jenis Kemasan Plastik Polietilen dan Polipropilen terhadap Umur Simpan Abon Ikan Tongkol (Katsuwonus pelamis) dengan Pendekatan Metode Arrhenius (M. Rizki Arifandy Saragih, Ismail Sulaiman, Martunis)

Jurnal Ilmiah Mahasiswa Pertanian, Vol. 4, No. 2. 2019: 317-328 


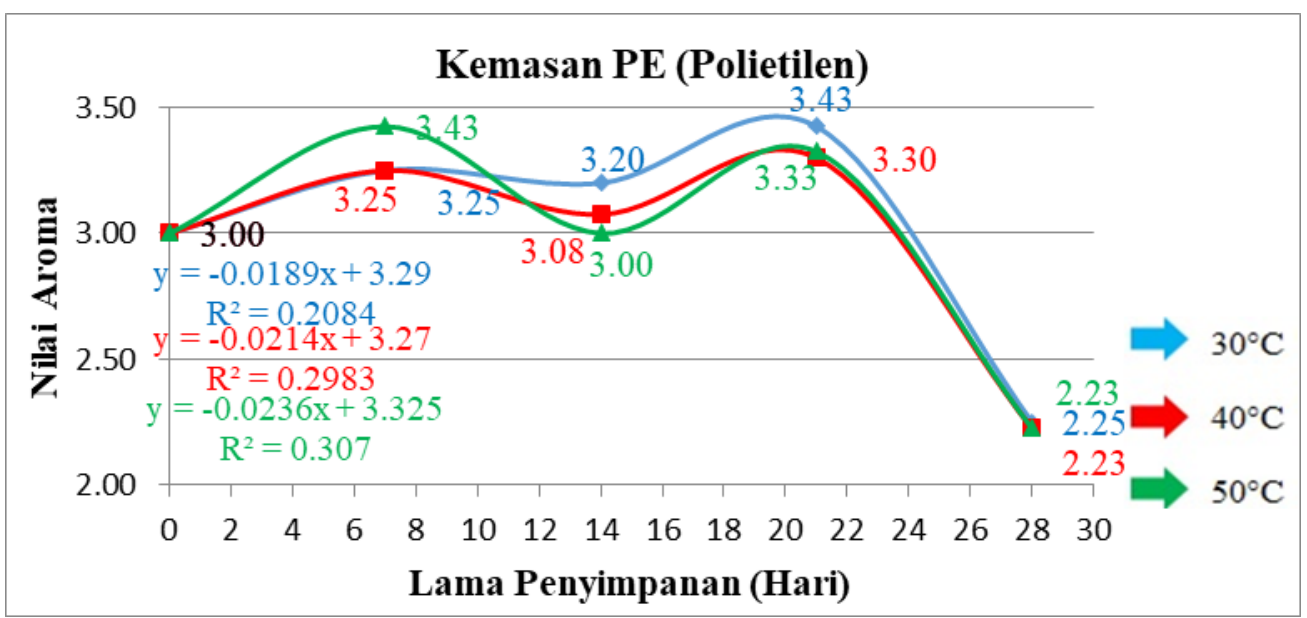

Gambar 9. Grafik perubahan nilai aroma abon ikan dengan kemasan PE pada perbedaansuhu dan lama penyimpanan.

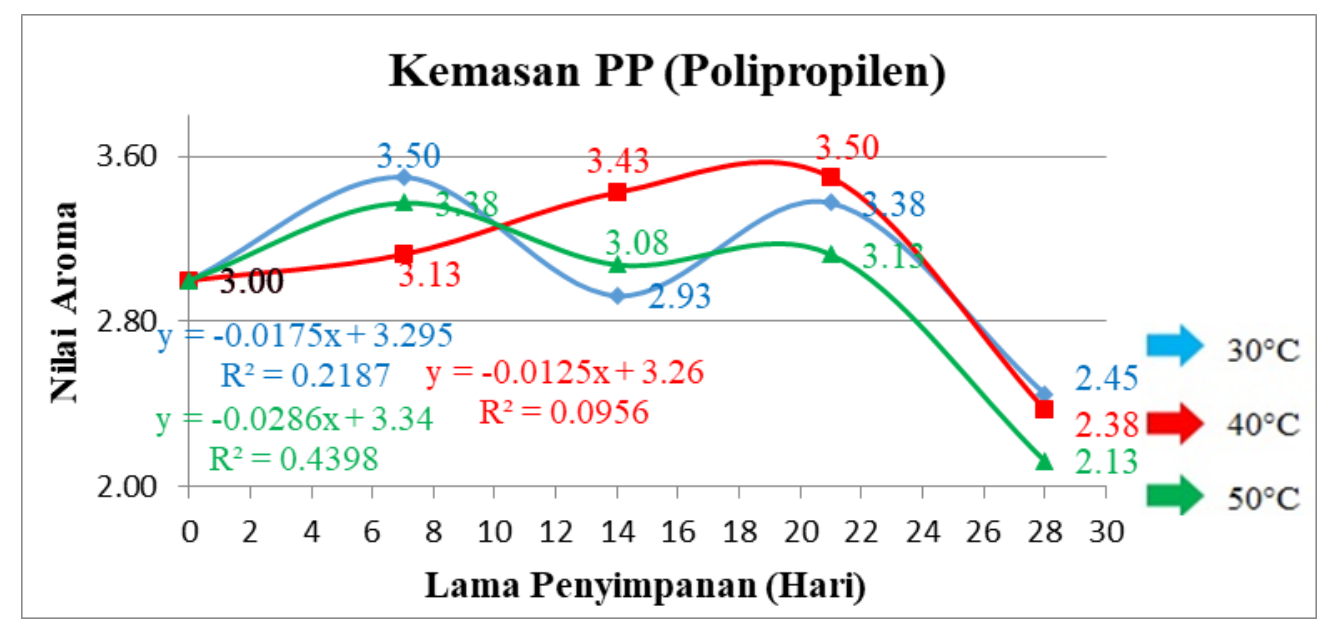

Gambar 10. Grafik perubahan nilai aroma abon ikan dengan kemasan PP pada perbedaan suhu dan lama penyimpanan.

\section{Tekstur}

Hasil analisis tekstur pada kemasan PE (Gambar 11) berkisar antara 2,32-2,55 dengan rata-rata 2,63 sedangkan pada kemasan kemasan PP (Gambar 12) berkisar antara 2,55-4,42 dengan rata-rata 2.74. Dari hasil pengamatan diambil rata-rata setiap uji dan parameter dan didapatkan bahwa tekstur abon ikan mengalami penurunan menjadi kasar selama penyimpanan. Hasil analisis regresi linier menunjukkan nilai koefisien determinasi $\left(\mathrm{R}^{2}\right)$ berbeda-beda. Pada suhu $30^{\circ} \mathrm{C}$, nilai koefisien lebih rendah yaitu 0,2644 dibandingkan dengan nilai koefisien pada suhu $40^{\circ} \mathrm{C}(0,2899)$ dan lebih rendah dibandingkan dengan suhu $50^{\circ} \mathrm{C}(0.0151)$ selama penyimpanan.

Pengaruh Jenis Kemasan Plastik Polietilen dan Polipropilen terhadap Umur Simpan Abon Ikan Tongkol (Katsuwonus pelamis) dengan Pendekatan Metode Arrhenius (M. Rizki Arifandy Saragih, Ismail Sulaiman, Martunis)

Jurnal Ilmiah Mahasiswa Pertanian, Vol. 4, No. 2. 2019: 317-328 
Penurunan tekstur abon ikan berhubungan dengan kadar air yang terkandung selama penyimpanan. Penurunan kadar air selama penyimpanan menyebabkan abon ikan yang dihasilkan semakin kasar. Hal ini sesuai dengan Purnomo (1995), yang menyatakan bahwa kadar air suatu bahan pangan dapat mempengaruhi tekstur dari bahan pangan tersebut.

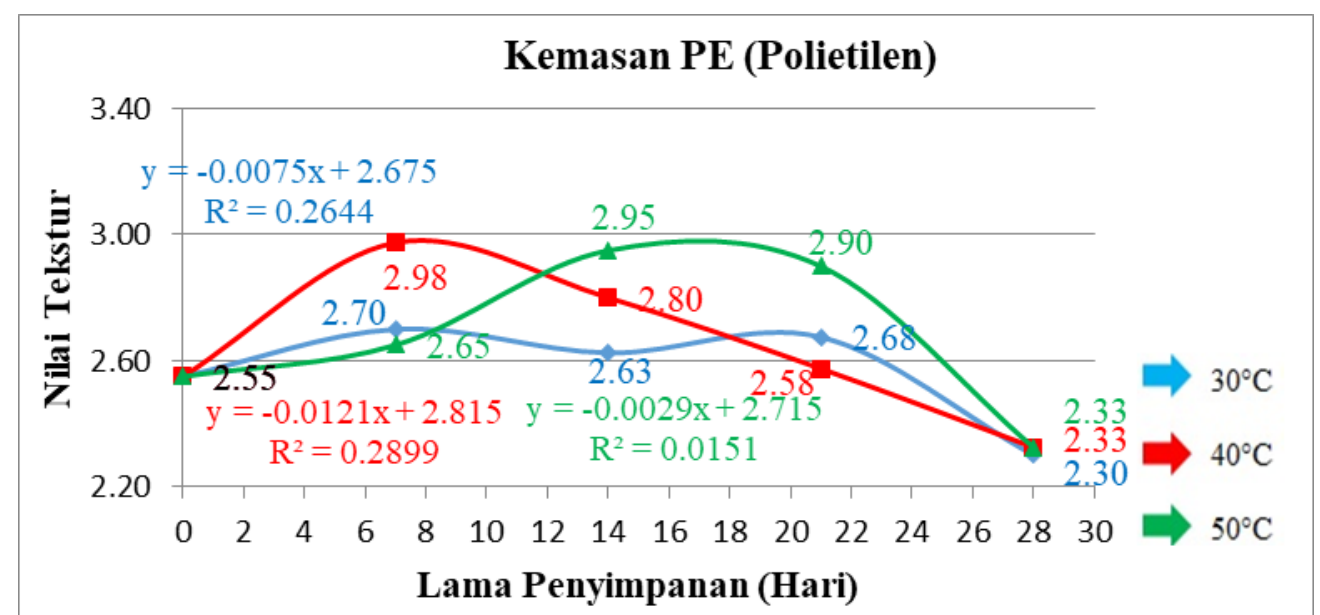

Gambar 11. Grafik perubahan nilai tekstur abon ikan dengan kemasan PE pada perbedaan suhu dan lama penyimpanan

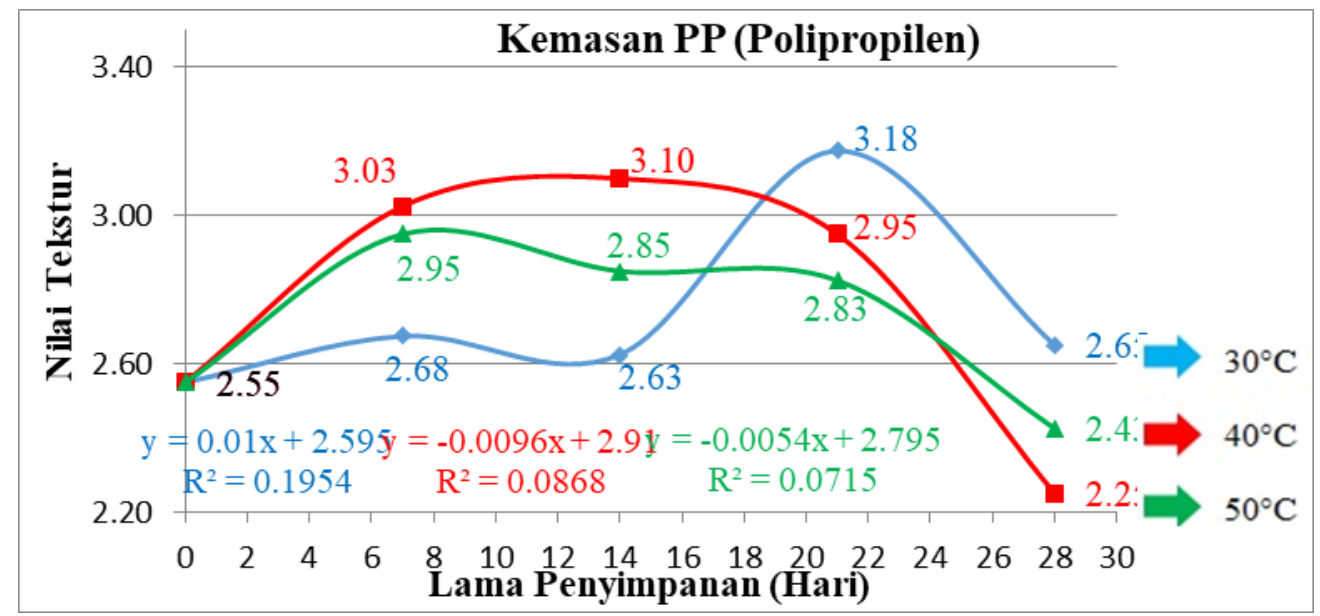

Gambar 12. Grafik perubahan nilai warna abon ikan dengan kemasan PP pada perbedaan suhu dan lama penyimpanan.

\section{Perhitungan Umur Simpan Abon Ikan}

Pengaruh Jenis Kemasan Plastik Polietilen dan Polipropilen terhadap Umur Simpan Abon Ikan Tongkol (Katsuwonus pelamis) dengan Pendekatan Metode Arrhenius (M. Rizki Arifandy Saragih, Ismail Sulaiman, Martunis)

Jurnal Ilmiah Mahasiswa Pertanian, Vol. 4, No. 2. 2019: 317-328 
Berdasarkan perhitungan metode akselerasi model Arrhenius (Tabel 1) diperoleh bahwa umur simpan abon ikan dengan kemasan PE adalah 113 hari sedangkan kemasan PP adalah 63 hari. Abon ikan yang dikemas dengan PE memiliki umur simpan yang lebih lama dibandingkan dengan dengan abon ikan yang dikemas dengan PP.

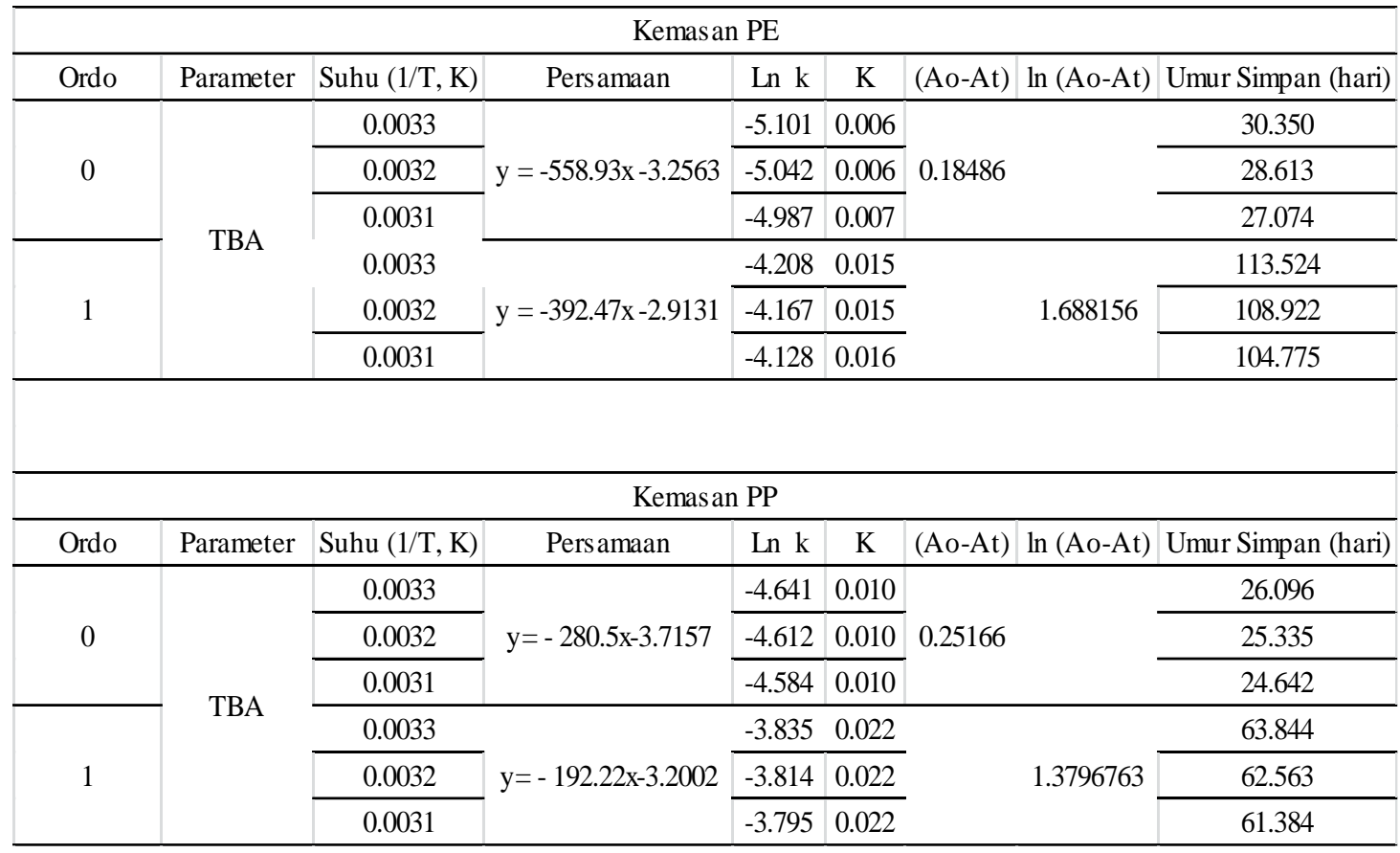

Hasil perhitungan pendugaan umur simpan abon ikan dengan kemasan PE dan PP menunjukkan bahwa semakin tinggi suhu penyimpanan maka umur simpan produk semakin pendek. Menurut Tridiyani (2012), hal ini diduga karena laju reaksi oksidasi lemak meningkat seiring meningkatnya suhu, sehingga menimbulkan aroma tengik yang tidak disukai oleh panelis.

\section{KESIMPULAN}

Penurunan nilai mutu ditandai dengan adanya aroma tengik pada abon ikan yang diketahui melalui nilai TBA dan organoleptik. Kemasan terbaik untuk melihat pendugaan umur simpan pada abon ikan adalah kemasan PE karena memiliki nilai umur simpan yang paling tinggi. Umur simpan abon ikan berdasarkan metode Arrhenius diperoleh dari peningkatan nilai TBA pada ordo satu dengan kemasan PE $\ln \mathrm{k}=-392,470 *(1 / \mathrm{T})-2,913$ adalah \pm 113 hari dan kemasan PP $\ln \mathrm{k}=-$ $192,22 *(1 / \mathrm{T})-3,200$ adalah \pm 63 hari pada suhu $30^{\circ} \mathrm{C}$. 


\section{DAFTAR PUSTAKA}

Arizka, A.A., dan J. Daryatmo. 2015. Perubahan Kelembapan dan Kadar Air The Selama Penyimpanan pada Suhu dan Kemasan yang Berbeda. Jurnal Aplikasi Teknologi Pangan. Vol. 4 N0. 4. 2015.

Azriani, Y. 2006. Pengaruh Jenis Kemasan Plastik dan Kondisi Pengemasan Terhadap Kualitas Mi Sagu Selama PEnyimpanan. Skripsi. Institut Pertanian Bogor, Bogor

Budiyanto, M.P. 2012. Pengaruh Jenis Kemasan dan Kondisi Penyimpanan Terhadap Mutu dan Umur Simpan Produk Keju Lunak Rendah Lemak. Skripsi. Fakultas Ekologi Manusia. Institut Pertanian Bogor, Bogor.

Hafriyani, Hidayati dan Elfawati. 2008. Kualitas Daging Sapi Dengan Kemasan Plastik PE (Polyethylen) dan Plastik PP (Polypropylen) Di Pasar Arengka Kota Pekanbaru. Jurnal Peternakan. Vol. 5. No. 1.

Nur, M. 2009. Pengaruh Cara Pengemasan, Jenis Bahan Pengemas, dan Lama Penyimpanan Terhadap Sifat Kimia, Mikrobiologi, dan Organoleptik Sate Bandeng (Chanos chanos). Jurnal Teknologi dan Industri Hasil Pertanian. Vol. 14, No.1 (Maret, 2009).

Martunis, 2012. Pengaruh Suhu dan Lama Pengeringan Terhadap Kuantitas dan Kualitas Pati Kentang Varietas Granola (Effect of Drying Temperature and Time to Quantity and Quality of Potato Starch Variety of Granola). Jurnal Teknologi dan Industri Pertanian Indonesia. Vol. 4. No. 26.

SNI 01-3707-1995. Syarat Mutu Abon. Badan Standarisasi Nasional Indonesia.

Sugiarto, T.I., Nusi., A.S Naiu dan F.A. Dali. 2015. Pendugaan Umur Simpan Abon Ikan Tongkol Asap. Jurnal Ilmiah Perikanan dan Kelautan. Vol. 3, No.3, September 2015.

Sutaryo., H. Rizkiqiati., Warsiti dan Listiyana. 2008. Aktivitas Anti Mikroba Dan Antioksidan Kunyit Pada Abon Sapi Oven. Laporan Penelitian, Universitas Diponegoro, Semarang. Suryani, A., E. Hambali dan E. Hidayat. 2005. Membuat Aneka Abon. Penebar Swadaya, Jakarta Tridiyani., A. 2012. Perubahan Mutu Abon Ikan Marlin (Istiophorus sp.) Kemasan Vakum dan Non Vakum Pada Berbagai Suhu Penyimpanan Dan Pendugaan Umur Simpannya. Departemen Teknologi Hasil Perairan, Fakultas Perikanan dan Ilmu Kelautan. Institut Pertanian Bogor, Bogor. 